\title{
Tanpınar Metninden Mimari Kesit Üretimi Aracılığıyla Kentsel Değişim Olgusunun İncelenmesi
}

\author{
Senem DOYDUK ${ }^{1 *}$
}

ÖZ

Günümüzde, metin-mekân ilişkisinin, modern felsefe ve edebiyatın bir yandan ana kaynağını oluştururken; bir yandan da bu ikilinin her bir ögesinin birbirini tarifi için temel bir mecra haline geldiği gözlenebilir. Bu bağlamda, mekânın anlamı ile mekânın temsili arasındaki doğrudan ilişkiye dair düşünsel zeminden yola çıkıldığında, mekânın bilişsel olarak algılanmasında planimetrik temsillerin yanı sıra mekânın üç (ve daha öte) boyutlu içeriğinin ifadesinde 'kesit' çizimlerinin oynadığı rol, mimarlık eğitiminde de çok üzerinde durulduğu üzere, oldukça hayati bir nitelik sergiler. Bu çerçeveden değerlendirildiğinde mekânın betimlenmesinde dil olgusunun, metnin ve kesitin kurduğu ilişki henüz çok irdelenmemesine rağmen çok geniş bir potansiyel sunan verimli bir kesişim alanıdır. Bu nedenle, bu ilişkinin irdelendiği bir akademik-mimari çalışma üzerinden, 'nesne-anlam-temsil' kavramları bağlamında, 'metin-mekân-kesit' üçgenindeki ilişkiler ağına odaklanılmıştır.

Anahtar Kelimeler: Ahmet Hamdi Tanpınar, metin mekân ilişkisi, anlam temsil ilişkisi

\section{A Review of Urban Transformation Phenomenon Through Section Production of Tanpınar's Literary Text}

\begin{abstract}
The relation between text and space constitutes the main source of modern philosophy and literature on the other hand each member of this relation becomes a basic course to specify the other's description. In this context, particularly having moved from the theoretical ground regarding the direct relationship between the meaning of space and its representation, the role that 'section drawings' played in the expression of the 3D (and even beyond) content of the space \{in addition to its planimetric representations\} in the cognitive perception of the space displays a highly vital character. When it's evaluated from this context, even the relation between text and section did not examined yet, the language fact in describing the space is a productive intersection area by submitting a broad potential. Therefore, it's been focused to the relation networks in the "text-space-section" triangle, upon an academic-architectural study examining this relation, in the context of "object-content-representation" concepts.
\end{abstract}

Keywords: Ahmet Hamdi Tanpınar, text-space relation, content-representation relation

\footnotetext{
${ }^{1}$ Sakarya Üniversitesi, Sanat Tasarım ve Mimarlık Bölümü, Mimarlık Bölümü, *ilgili yazar / Corresponding author: sdoyduk@sakarya.edu.tr Gönderim Tarihi: 06.04.2016

Kabul Tarihi: 17.05.2017
} 


\section{GíRiş}

Sakarya Üniversitesi Mimarlık Bölümü lisans birinci sınıf öğrencileri ile Mimari Tasarıma Giriş dersi kapsamında, dört hafta boyunca Ahmet Hamdi Tanpınar'ın Beş Şehir isimli kitabı aracılığıyla, şehirlerdeki değişim olgusu ve metin-mekân ilişkilerinin sorgulanması çalışmaları gerçekleştirildi. Ankara, Erzurum, Konya, Bursa ve İstanbul şehirlerine dair metinler, soru sorma aracı olarak kullanılıp, Tanpınar'ın günümüzden yaklaşık 50 sene önce kaleme aldığı şehirlerin geçmişlerine ve o döneme dair anlatısı, bugünün şehir gözlemcileri olan üniversite öğrencileri tarafından yorumlandı. Bir diğer deyişle, metinler aracılığıyla günümüzden Tanpınar dönemine ve Tanpınar'ın kendi zamanından geriye dönerek aktardığı tarihsel anlatıya uzanan kronolojik ilişkiler çözümlenmeye çalışıldı. Şehirlerdeki değişim, bu değişimin hızı ve kişiler üzerindeki etkisine dair; hem Tanpınar'ın yargıları hem de öğrencilerin algıları birlikte tartışıldı. Değişim olgusundaki olağanlık ve hızındaki olağan dışılık; metinlerin yapısından üretilen mekânsal dizgilemeler (redaksiyon) ile soyutlandı. Mekân ve şehirlere dair bilgi, metin üzerinden okunarak elde edilmeye çalışıldı (Çağlar ve Ultav, 2004, s. 43). Metinmekân ilişkilerinin sorgulanmasındaki temel amaç; öğrencilerin mimarlık eğitimleri boyunca, mekân tasarlama, çözümleme, mekândan anlamlar üretme gibi ilişki biçimleri kurarlarken, araçlarının (fiziki, mekânsal, yapısal, inşai vb. unsurlarla) sınırlı olmadığı vurgusunu yapabilmekti. Öğrencilerin şu keşfi yapmaları amaçlanmıştır: Mekânı anlama ve üretme deneyimini besleyen girdilerden; kullanıcı intiyaçları, çevre verileri, yasal prosedürler, teknolojik olanaklar, kültürel sürekliliklerin yanı sıra, bir edebiyat metni ile ilişki kurmak da, mekân üretimini arttırıcı bir etkiye sahiptir. Öğrencilerden, edebiyat metninin içeriğindeki mekânların kesitlerinin alınması, bunun yanı sıra -mimari temsil olgusu ve bunu ifade etmenin araçları arasında o mekânda gerçekleşecek gündelik hayata, en yaklaşan temsil araçlarından biri olan (Hewitt, 1985)- kesitlere Tanpınar'ın bu mekânlara yüklediği anlamlara dair kişisel değerlendirmelerini işlemeleri beklendi. Tanpınar metinlerinde söz edilen şehirlerdeki değişim olgusu, kesit çizimleri aracılığıyla yorumlanmıştır. Metinlerdeki değişim olgusu ile güncel olan, deneyimledikleri değişim olgusu arasındaki hız farkının ortaya konması amaçlanmıştır.

Bu çalışmada, Tanpınar metni üzerinden dilbilimsel bir çözümleme yapılmaktadır. Bu çözümleme için, mimari bir temsil aracı olan kesit çalışmaları araçsallaştırılmıştır. Kesit temsilinin mekânın algılanması ve kavranmasındaki önemi kapsamlı biçimde araştırılmış bir konudur (Bafna, 2008). Geleneksel mimari temsil araçlarından -plan, kesit ve görünüşten- kesitin tercih edilmesinin nedeni, yukarıda da değinildiği gibi, öğrencilerin, metin içerisinde anlatılan mekânların içine girip, durumla cepheden karşılaşmalarını sağlamaktır. Mekânlara üstten (plan) ya da dıştan (görünüş) bakmak yerine, mekânlardaki durumların-olayların içine dahil olabilmek için kesit temsili önerilmiştir, ancak diğer temsil araçlarıyla ifade etme yoluna giden öğrenciler de engellenmemiştir. Çalışmadaki amaç, Tanpınar metinlerinden mimari temsil ürünleri yaratmak değil, Tanpınar deneyimleri ile ilişkiye geçmelerini sağlamaktır.

Mekân-metin-temsil ilişkiler üçgeninde, mekânı metin üzerinden dolaylı olarak algılayan subjenin, mekânı temsil olgusunu ve onun araçlarını kendi oluşturduğu yeni metni mekânsal olarak soyutlamak amacıyla kullanma eğiliminde olduğu çıkarımı yapılabilir. Birçok mimarlık kuramı; temsillere, tasarımcının vazgeçemeyeceği araçsallıkta anlam yükler (Turan, 2011; Tan, 2013; Gürer ve Yücel, 2005). Ancak bu çalışma; mekânın temsil araçlarıyla ifade edilmesi konusuna odaklanmadığı için, öğrencilerin geleneksel mimarlık temsillerine ne kadar uydukları değil, Tanpınar anlatısını ne miktarda içselleştirip eleştirdikleri ve yorumladıkları üzerinden değerlendirilmiştir. Metin üzerinden dilbilimsel çözümlemeler yapma denemesi, mimari temsil araçlarının 
yorumlanması bağlamında, öğrencilere, gelecek dönemlerde yoğunlaşacakları tasarım pratiğinde yeni bir uzam açma hedefi taşımaktadır.

ı. Calvino'nun Hayali Kentler kitabı üzerinden üretilen, metin aracılığıyla mekânsal iz sürme çalışmalarına mimarlık eğitiminde sıklıkla rastlanmaktadır (Calvino, 2002). Bu çalışmada Türk Edebiyatçıları arasından Tanpınar'ın seçilmesi, metinlerinde kendisinin mekâna yüklediği anlamdan kaynaklanmaktadır ve bu seçimin temel nedeni, mekânı bu derece yoğun işleyen başlıca yazarlardan biri olmasıdır. Yazarın farklı romanlarında mekânsal anlatının değeri değişir ancak Beş Şehir'de kitabın ana konusu, mekânın kendisidir. Beş Şehir üzerinden yapılan çalışmada, öğrencilerin yaş aralığı göz önüne alınacak olursa, oldukça yabancı oldukları bir dil ile ilişkiye geçmeye çabaladıkları söylenebilir. B. Tanju'nun (Tanju, 2007) Tereddüd ve Tekerrür başlıklı kitabında yer verdiği mimarlık ve kent üzerine metinler ile kurduğu dilbilimsel ilişkideki, kelimeleri Türkçeleştirme yöntemi anımsanacak olursa, altını çizdiği kelimelerin yoğunluğu kitabın en sonunda yer alan Tanpınar metnine ulaşıldığında çokça seyrekleşmiştir. Bu çalışmada ise, öğrencilerin aynı metin ile kurdukları Türkçeleştirme çabaları, Tanju'nun 1870'li yıllardaki metinler için kullandığı yoğunluk ve sıklıkta olmuştur. Lisans öğrencilerinden oluşan okuyucu grubunun 1950'li yıllara ait Türkçeyle olan ilişkisizliği, uzun bir sürenin yoğun sözlük kullanımına ayrımasını gerekli kılsa da, bu zorluk bir yandan da avantaja dönüşmüş, Tanpınar ifadelerini çözümlemek için sarf ettikleri çaba, metinle ilişkilerinin sıkılaşmasını ve daha derin bir anlamsal içeriğe ulaşmalarını sağlamıştır (Şekil 1). Öğrenciler, şehirlerin tarihlerini Tanpınar gözlemleri ve yargıları üzerinden okurken, Geç Osmanlı ve Erken Cumhuriyet Dönemi şehir yaşamındaki süreklilikleri ve kırılmaları sözü edilen mekânların günümüzdeki var/yok oluşları ile de değerlendirmeye çalışmışlardır.
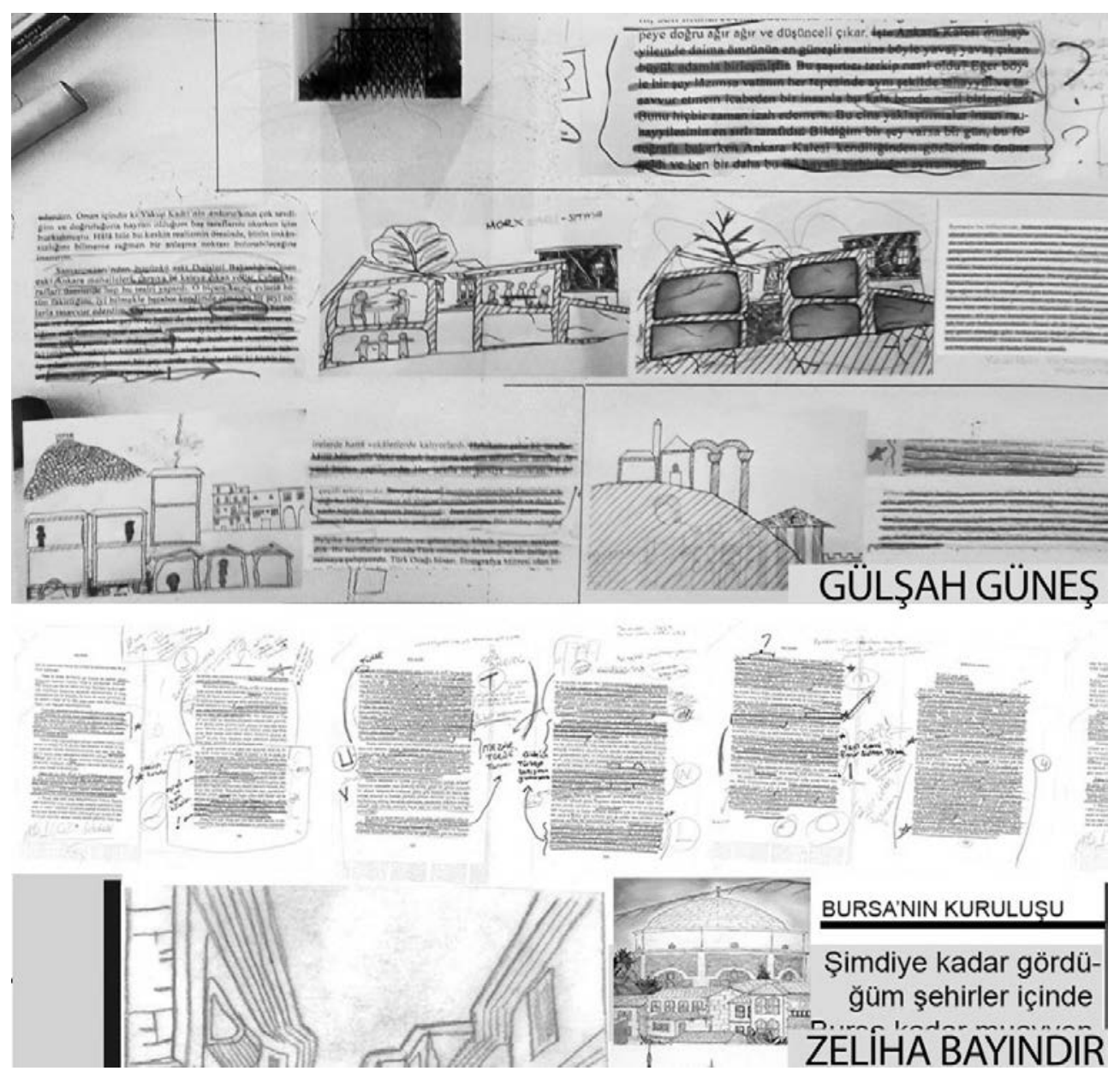
Tanpınar Metninden Mimari Kesit Üretimi Aracılığıyla Kentsel Değişim Olgusunun İncelenmesi

Şekil 1: Tanpınar metni ile kurulan ilişki. Gülşah Güneş ve Zeliha Bayındır'ın teslim paftalarında

yer verdikleri kitap metnine ait fotokopilerinden detaylar.

Yapılan çalışmaya Mimari Tasarıma Giriş dersini alan, 30 öğrenci katılmış; kitapta yer alan beş şehir, öğrencilerin seçimleri doğrultusunda paylaştırılmıştır. Öğrenciler, memleketleri ya da bir süre yaşamış olmaları gerekçeleriyle, bazıları ise, hiç tanımadıkları bir şehri öğrenebilme isteği ile seçimlerini yaptıklarını belirtmişlerdir. 11 öğrencinin çalışmasından bazı detaylara yer verilmiş, öğrenci çalışmalarının seçimi, makalede vurgulanmaya çalışılan temalarla ilişkileri bağlamında gerçekleştirilmiştir.

\section{PROJE SÜRECINE AKADEMIK DESTEKLER}

Mimarlık eğitimlerinin henüz başında olan öğrencilerle bu içerikli bir çalışmanın olası zorlukları, konu hakkında uzmanlıkları olan akademisyenlerin tematik sunumları ve destekleri ile en alt sınıra indirilmeye çalışılmıştır. Tanpınar'ın Geç Tanzimat ve Erken Cumhuriyet Dönemi edebiyat dünyasındaki pozisyonu ve öneminin yanısıra, yaşadığı dönem ve sonraki kuşaklar tarafından nasıl bir entelektüel zemine yerleştirilerek değerlendirildiğine dair akademik yayınlardan ve akademisyenlerin sunuşlarından faydalanılmıştır. Çalışmanın süresi ve kurgusu ile de ilişkili olarak, öğrencilerin bulundukları üniversitede üç etkinlik izleme olanağı sunulabilmiş, bu etkinliklere öğrencilerin tümü katılmıştır. İ. Şahin'in Haz ve Günah (Şahin, 2012) ile B. Dellaloğlu'nun Bir Tanpınar Fetişizmi (Dellaloğlu, 2011) gibi edebiyat araştırmalarının, sözü edilen akademisyenlerin öğrencilere yaptıkları sözlü sunumlar ile tartışmaya açılması, proje sürecine önemli katkılar sağlamıştır. Tanpınar'ın muhafazakâr ve modern dünya ikilemi bağlamında değişim olgusuna dair tutumu, bu sunumlar kapsamında yakın okuma [ayrıntılı akademik okuma (Zariç, 2014, s. 112)] yöntemi uygulanarak tartışmaya açılmıştır. A. N. Şenel'in master çalışması (Şenel, 2010) kapsamında Tanzimat Dönemi romanları üzerinden gerçekleştirdiği şehir rotalarını içeren sunumu aracılığıyla da, öğrencilerle edebiyat metni üzerinden mimari soyutlama örnekleri paylaşılmış ayrıca üretilen kesit soyutlamalarındaki üç boyutlu sunumlar için fikir üretme kanallarını açan tartışmalar yapılmıştır. Her bir akademik etkinlik, görsellerle desteklenmiş sözlü sunum yöntemiyle yaklaşık ikişer saat sürmüş, hepsinin son bölümünde, öğrencilerin sunum yapan kişilere sorular sorma ve çalışmalarını zenginleştirecek fikirler edinme imkânları olmuştur.

\section{TANPINAR'IN KONUMLANDIĞI ENTELEKTÜEL ZEMIN}

Proje sürecinde gerçekleştirilen üç akademik sunuş kapsamında, Tanpınar'ın bir entelektüel olarak nasıl pozisyonlandırıldığı farklı disiplinlerin bakış açıları doğrultusunda tartışılmış, bu da öğrencilerin Tanpınar metinlerine yaklaşımlarına etki etmiştir. Çalışma kapsamında, salt var olan metnin söylediklerine odaklanmanın ötesinde, metnin anlatıcısının düşünsel, politik, entelektüel yönleri de irdelenmiş, böylece, değişim olgusunun değerlendirilmesi, yazarın perspektifinden ait olduğu dönemin değerleri üzerinden incelenme imkânı bulunmuştur. Türk edebiyat ve sanat dünyasında üretim yapan entelektüel öznelerin kolaylıkla yerleştirildiği politik konumlardan farklı olarak Tanpınar'ın ne modern ne de muhafazakâr kanat tarafından sahiplenilmeyen bir dönem kişiliği olduğuna değinen araştırmacılar, bunun yaşadığı dönem için de geçerli bir durum olduğunu belirtmişlerdir. "Günlüklerin Işığında Tanpınar'la Başbaşa" isimli çalışmaya referansla (Engigün, 2008) Tanpınar'ın yaşamı boyunca, beklenti içinde olduğu takdiri kazanamaması, döneminin modern kalemlerinden farklı olarak Batılı referanslar yerine mimarlık bilgi alanından bakıldığında gelenekçi (araştırmacıların muhafazakâr olarak nitelendirdiği) kaynaklara olan bağlıı̆̆ı Tanpınar'ın konumlandırılamamasındaki gerekçeyi oluşturur. Cumhuriyetçi entelektüel çevre ile yakın ilişkili gündelik hayatı, CHP milletvekilliği 
görevi, Baudelaire gibi dönemi için ilerici olarak nitelendirilebilecek yazarları takip etmesi ile modernist bir çizgi sergileyen Tanpınar, metinlerinde Süleymaniye, Mimar Sinan, Itri, Dede Efendi referansları ile gelenekçi değerleri öne çıkartır. Siyasi kimliği ile kültürel kimliği arasındaki alışıımışın dışındaki çelişki, Tanpınar üzerine gerçekleştirilen tartışmalarda önemli bir yer tutmuştur. Geleneksel olana değer veren ve ona özlem ve hayranlığını açıkça ifade eden Tanpınar, özel hayatındaki seçimleri, bohem yaşam tarzı, okudukları, dinledikleri, milletvekilliği, arkadaş çevresi ile 'modern' bir hayat sürmüştür. Tanpınar metinlerindeki güçlü retorik, belki de iç dünyasında yaşadığı bu çelişkilerden beslenmiştir. Öğrencilerin sunum yapan araştırmacılara yönelttikleri sorular ağırlıklı olarak Tanpınar'ın kullandığı mekânlarla ilişkili olduğu gözlenmiştir. Kişilerin iç dünyası ve ideolojik yaklaşımlarının yaşamayı seçtikleri mekâna yansıyıp yansımadığını sorgulayan öğrenciler, Tanpınar'ın uzun yıllar barındığı Narmanlı Han binası ile olan ilişkisi, handa kullandığı odanın iç düzenlemesine ait konular tartışmaya açılmıştır. Bu sunumlarda gerçekleşen tartışmalar kapsamında; duyarlı bir entelektüel olan Tanpınar'ın kişiliğinin irdelenmesi, mekâna dair yaptığı saptamaları daha anlaşılır kılmıştır.

Tanpınar'ın metinlerinde eski ile yeni, geçmiş ile güncel arasındaki ilişkiyi yerme ama aynı zamanda da olumlama eğilimli olduğu gözlenir. Değişim yani geçmiş dönemlerle olan derin farklılaşmaları, çoğu zaman hasretle ve geleneksele verdiği değer ile aktarır. Geçmiş dönemlere dair özlemini belirtirken, o dönemleri, neredeyse yaşadığı güne taşıma arzusu içindedir: Tanpınar'ın şu sözleri, zaman-dönüşüm, ve bu ikilemin içkin çelişkilerini, yazarın kendi iç çelişkileriyle de özdeşleştirdiği söylenebilir; "...Fakat bu hasret sade geçmiş zamana ait olan ve bugünkü hayatımızla, mantığımızla zaruri olarak çatışan bir duygu değildir" (Tanpınar, 2008, s. 119). Ancak, kitapta Cumhuriyet ile gerçekleşen değişimi olumladığı görülür, yeni medeniyet durumunu kabullenmemiz gerektiğini vurgular. Şehri şehir yapan şeylerden biri hiç şüphesiz ki "değişim" olgusudur. Bu gerçekliği kabul etmiş; söz konusu olağandışılığın değişimdeki hız unsuru olduğunu öne sürer. Değişimin hızı, şehrin geçmişini, yaşanmışlıklara ait izleri okuma imkânını ortadan kaldırmaktadır. Bir diğer deyişle, değişim olgusu olağan ve olumlu olarak nitelenirken, hızının mekânlar ve insanlar üzerinde sebep olduğu tahribatlar Tanpınar'ı incitmiştir. Öğrencilerle yapılan tartışmalar kapsamında, Tanpınar'ın memnuniyetsiz olduğu değişimin hızı ile günümüzdeki değişimin içeriğinin karşılaştırmaları yapılmıştır. Tanpınar; Erken Cumhuriyet Dönemi'nin, geleneksel dönemlere dair izleri silmiş olmasını konu ederken, öğrencilerin günümüzde şehirlerde geçmişe ait hemen hemen hiçbir izin okunamadığı yargısında oldukları gözlenmiştir. Tanpınar'ın dünya algısını oluşturan entelektüel kişiliğinin de çalışmaya dâhil edilmesi, metinlerdeki dilin arkasındaki dilbilimsel sistematiğin (Whorf, 1956) çözümlenmesine olanak vermiştir.

\section{4. ÖĞRENCI ÇALIŞMALARINDA TANPINAR ŞEHIRLERI}

Tanpınar satırlarındaki şehir anlatıları, salt fiziksel gözlemler değil, kişisel duygularla birlikte işlendiği için, öğrencilerin kurguladığı mekânsal kesitler de salt mimari mekânları değil, mekânlara dair algıları aktarabilmeyi hedeflemiştir. Gözle görülen (optik) ya da tenle algılanan (haptic) (Pallasma, 2011) mimari imgeler üzerinden değil, metin-söz-söylem üzerinden araştırılmıştır. Göz-görme merkezli değil, logosentirik-söz ve dil merkezli bir araştırma yöntemine gidilmiştir. Mekânlarda göz ile yapılan (optik) görsel okuma statik ve durağan iken, metindeki sözlü bilgiler ile daha soyut bir ilişki içine girilmiş ve daha dinamik yorumlamalar yapılabilmiştir, Tanpınar'ın deneyimleriyle başbaşa kalabilmek için, gözle ya da tenle değil, metin aracılığıyla bir mekânsal ilişki geliştirilmeye çalışılmıştır. Satırlardaki kelimelerin ötesinde, satır aralarına sızan olası sözlerin öğrencilerde yarattığı etki, Tanpınar şehirlerinin kesitleri üzerine ikincil kimi 
örneklerde üçüncül kesitler üretilmesini sağlamış, kesitler katmanlaşmıştır. Burada, mekândaki anlamsal ve algısal katmanlaşmanın mimari temsil tekniklerindeki katmanlaşmayla betimlenmesi dikkat çekicidir. Kişisel algıların da çalışmalara ekleniyor olması, kimi çalışmalarda sunum tekniğine de yansımıştır. Metindeki tanımlamalar üzerinden ve diğer kaynaklardan araştırılan fiziksel mekânlara dair anlamsal çözümlemelerin yanında, bu mekânlara yüklenen anlamlar da kesit içeriklerinde soyutlanarak aktarılmıştır.

Şehir anlatılarındaki mekânlar, algıların işlenmesi yoluyla içindeki yaşantıların ve duyguların aktarıldığı marjinal, değişken, fantastik, duygusal, metafizik, olgusal mekânlar gibi içeriklerle çeşitlendirilmiştir (Şengül, 2010) (Şekil 2). Ankara metninde Alaeddin Keykubat'ın sürgün olarak yaşadığı kapalı-dar mekân (Tanpınar, 2008, s.21) bir çalışmada "marjinal mekân" olarak yorumlanıp medrese kesiti, hapishane psikozu ve "ölüm korkusu" teması ile soyutlanırken (Şekil 2), bir diğer çalışmada medrese, "muhasara günlerin hatırası", "karışık bir hayatın mekânı" olarak yorumlanmıştır (Şekil 2). Konya metninde hapishanenin kadınlar koğuşundan gelen seslerin ve "bir avuç zehire" benzettiği türkülerin (Tanpınar, 2008, s.91) Tanpınar'ın içinde bulunduğu mekâna etkisinin çalışıldığı kesitte, Tanpınar'ın evinin hücreleşmesi (Şekil 2), bir diğer kesitte ise yüzünü görmediği kadın tutukluların sesi ile duvarların genişlerken Tanpınar evinin yüzeylerinin büzüşmesi olarak yorumlanmıştır. Öğrenci kesitlerinde Tanpınar'ın odasının fiziksel boyutları nedeniyle değil, hapishaneden gelen kadının sesi ile hissettiği sıkışıklık duygusu nedeniyle mekân hücreleştirilmiştir. Konya şehrinde II. Kılıçarslan'ın oğulları arasında başlayan kanlı saltanat kavgaları (Tanpınar, 2008, s. 77), öğrenci çalışmasında üçgen form kullanılarak şemalaştırıımış, insan-mekân-iktidar savaşı üçgenlerin kesişimleri üzerinden kurgulanmıştır (Şekil 2). İktidar mücadelesinin mekânda yarattığı anılar, mekâna yüklediği anlam ve olgusal mekân oluşumu (Korkmaz, 2007), öğrenciler tarafından üçgen biçimler ile şemalaştırılmış, Tanpınar'ın mekân anlatısındaki kişi-yer ilişkileri sorunsallaştırılmıştır (Gariper, 2012).
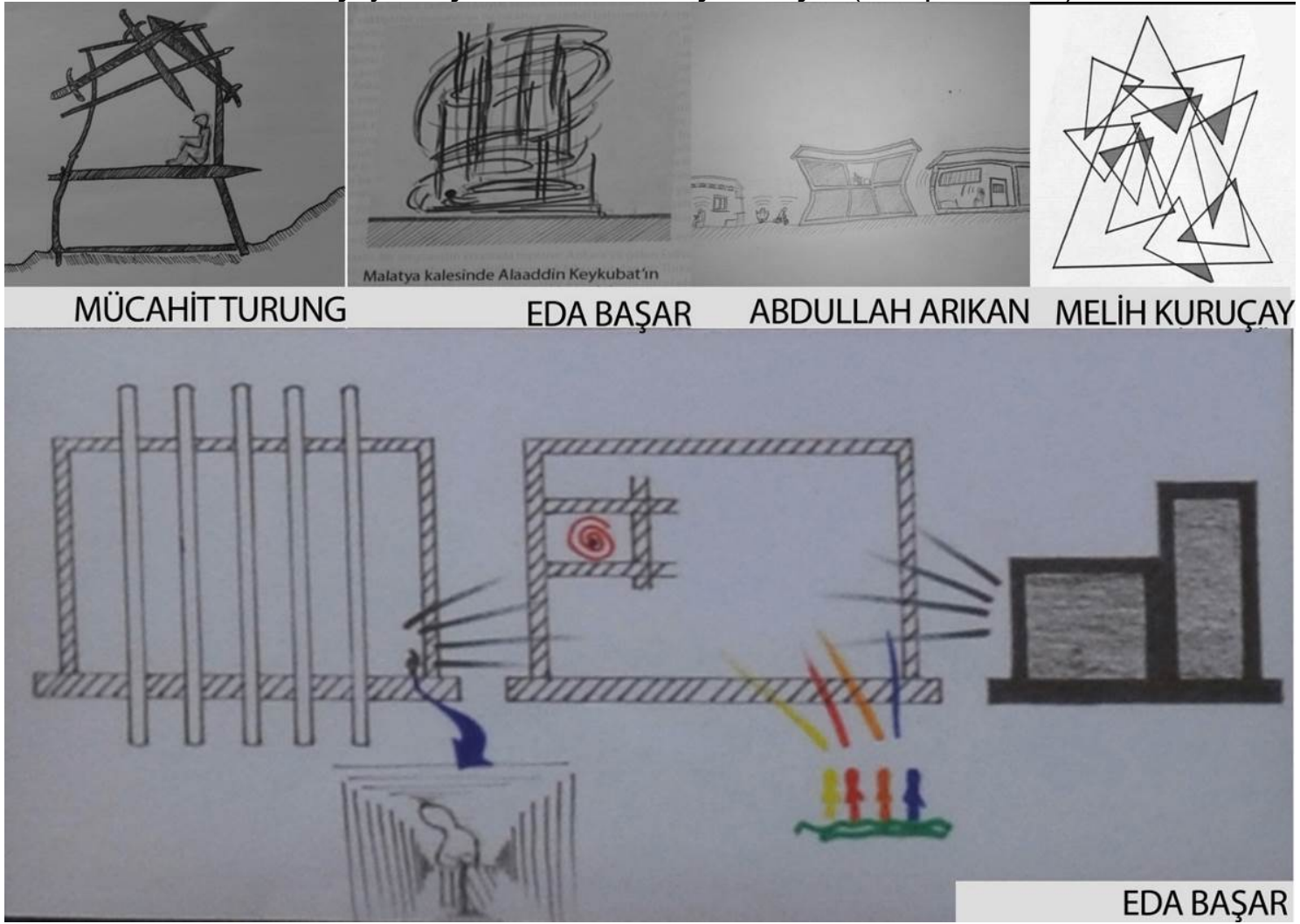
Şekil 2: Öğrenci çalışmalarından detaylar. Anlam üreten mekânların duyguları yansıtacak şekilde soyutlanma denemeleri. Mücahit Turung ve Eda Başar'ın "marjinal mekân”, Abdullah

Arıkan ve Eda Başar'ın “hücreleşen mekân”, Melih Kuruçay’ın “iktidar mekân” soyutlama çalışmaları.

Tek bir şehri çalışan öğrenciler, o şehre ait metindeki tüm olaylar dizgisini değil, metnin içinden kişisel kesitlerini kurgalayacak şekilde seçimler yapmışlar, kesitler aracılığı ile mevcut metni bir tür yapı-bozumuna uğratarak, kendi metinlerini yeniden inşa etmişlerdir. Süreklilik arz eden zaman algısı (yine yapı-bozumcu bir tavırla fragmanlaştırılarak), öğrencilerin kendi dönemsel izlenimleri ile kesintilere uğratılmıştır. Dolayısıyla projeler, anlamsal boşlukların olduğu, istem dışı olmayan "atlamalarısuskunlukları" içermektedir. Erzurum metni gibi kronolojik şehir anlatımlarından üretilen metinler bir sıra halinde, lineer bir olay kurgusu ile ifade edilirken (Şekil 3), Bursa şehrindeki zaman algısı deforme edilmiştir (Şekil 3). Ankara ve Erzurum metinleri bir olay örgüsü anlatımıyla roman, Bursa ve İstanbul metinleri ise çok zincirli olay halkaları nedeniyle şehir rehberi etkisi yaratmaktadır.

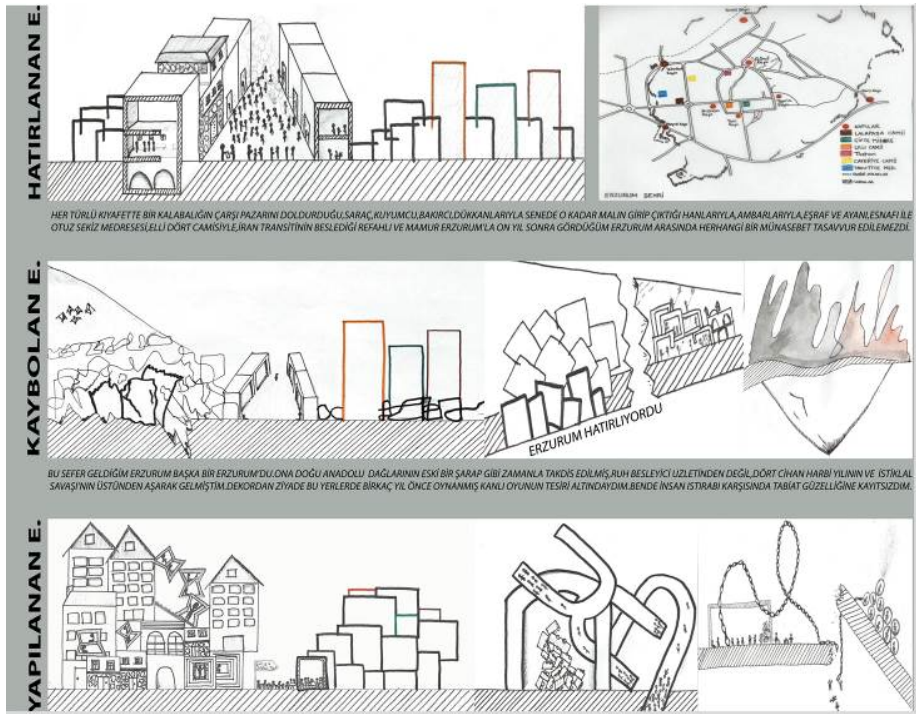

ASENA ERGÜN

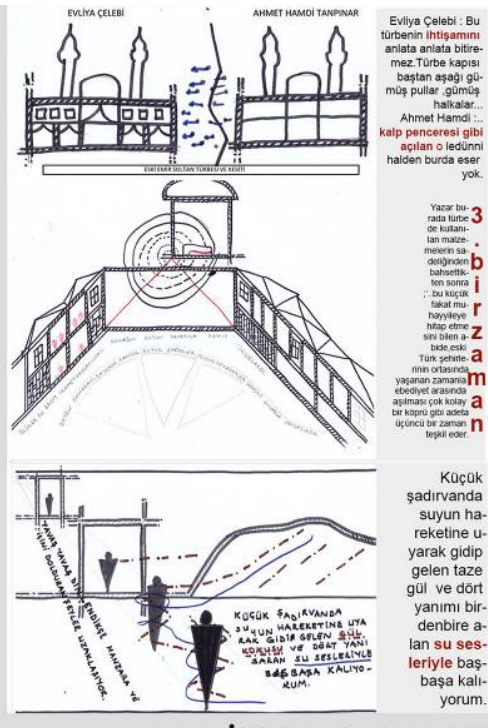

ZELIHA BAYINDIR

Şekil 3: Asena Ergun'un Erzurum ve Zeliha Bayındır'ın Bursa hikâyelerinin anlatımlarındaki zamansal farklılıklar.

Erzurum metninde ele alınan üç farklı dönem; çocukluğu -hatırlanan-, savaş ertesi kaybolan- ve tekrar gelişmekte olan -yapılanan- şehir olarak ayrıştırılmış, metinde anlatılan savaşın ve yıkımın şehir üzerindeki etkileri, çalışmalarda karanlık ve yoksunlukların mekânı olarak çalışılmıştır. Aynı şehirde yolculuk üzerinden yaptığı saptamalar, trendeki yataklı vagon yolculuğunu detaylandırdığı bir deneyim üzerinden aktarılmıştır (Tanpınar, 2008, s. 58). Bu metinde vurgulanan yalıtılmışlık duygusuna katılmayan öğrenci, her türlü yolculuk deneyiminin ister istemez insanların birbiri ile temasını sağladığını, ister tren ister bekleme holü olsun, burada toplu şekilde bulunan kişilerin, yalnız bir şekilde mekânda varlık gösterseler de, bir çeşit temas ve etkileşim içinde olduklarını vurgulamaya çalışmıştır (Şekil 4). Yük vagonu anlatısına yoğunlaşan bir çalışmada, insan-mekân ilişkisine değinilmiş, müziğin çizgiyi mekânsallaştırdığı ve mekânın müzik aracılığı ile hacim kazandığı anlatılmış, metin üzerinden yeni bir öyküleştirme çalışması yapılmıştır (Şekil 4). Sesin -soluk benizli çocukların sesinindemirden oluşmuş vagon mekânını nasıl erittiği çalışılmıştır (Şekil 4). Tanpınar'ın bir 
çaresizlik mekânı olarak aktardığı yük vagonu üzerine, öğrencinin kendi sosyal ve psikolojik yapısı ekseninde anlam ürettiği gözlenmiştir (Şahin, 2011, s. 1558).
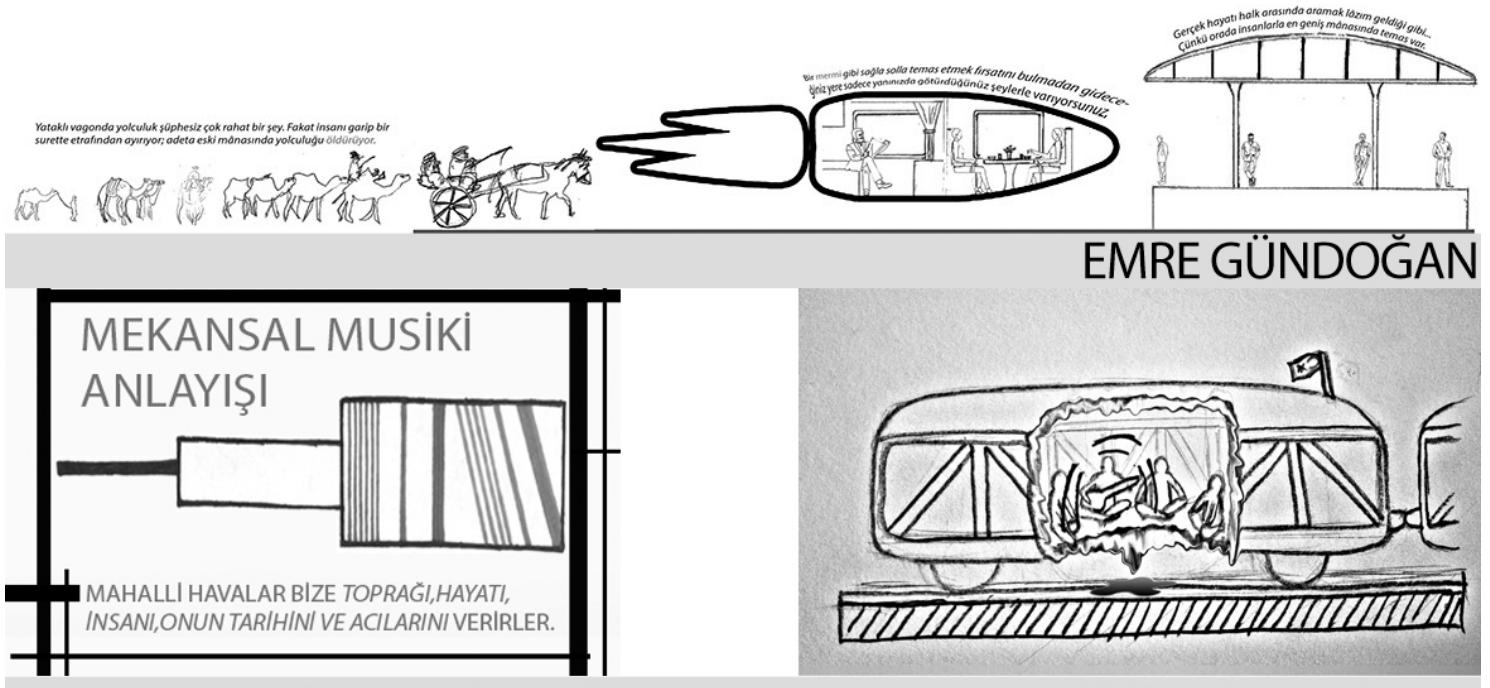

EMRE GÜNDOĞAN

MERYEM ZAFER

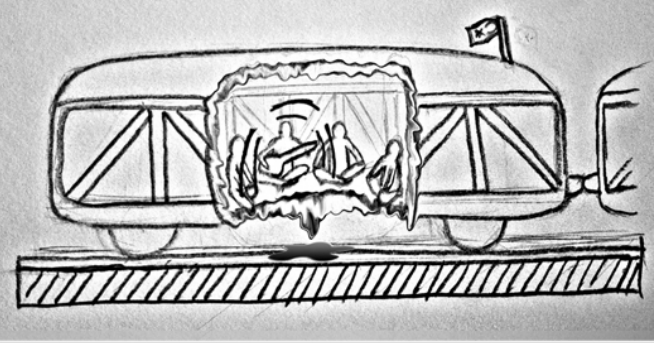

ABDULLAH ARIKAN

Şekil 4: Ses, insan ilişkisi, musiki gibi unsurların mekân kesitlerinde gösterimi. Yalıtılmışlık duygusuna itiraz eden Emre Gündoğan, müzik aracılığıyla hacim kazanan Meryem Zafer, sesle mekânın eridiği Abdullah Arıkan çalışmaları.

\section{5. ÖĞRENCI ÇALIŞMALARINDA ŞEHIRLERDEKİ DEĞişiM}

Alınan kesitlerin içeriklerinin işlenmesinde, metindeki; diyalog, açıklama, iç monolog, geriye dönüş ve metinler arası ilişki gibi anlatım tekniklerinden faydalanılmıştır. Bu farklı teknikleri kapsayan metinlerde, okura bırakılan duygusal atlamalar kimi çalışmalarda kesitin ana teması olarak kullanılmıştır. Tanpınar'ın farklı semt duygularını aktardığı metninde, insanın içini hüzün dolduran Çamlıca Tepesi etkisi ve Boğaziçi kıyılarında sabahın verdiği lezzet etkisini (Tanpınar, 2008, s.120), doğa-mekân-insan ilişkisi olarak ele alan öğrenci çalışması, bu etkilerin deniz ile olan mesafenin uzaklığından kaynaklandığı çıkarımını yapmıştır (Şekil 5).

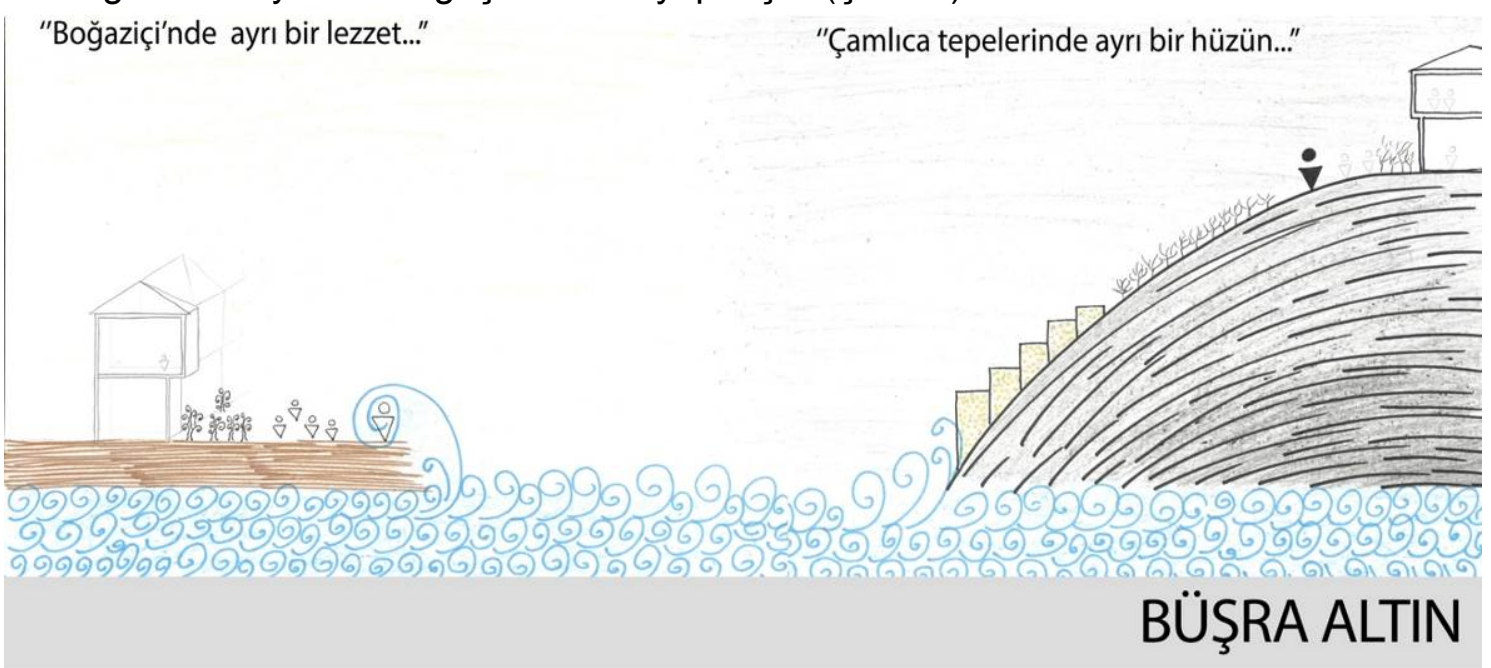

Şekil 5: Melankoli ve kamusal alan 
Tanzimat Sonrası Beyoğlu'nda gerçekleşen değişimi, "Şehrin hayatına artık yapıcı ve yıkıcı çehreleriyle girer", sözleri ile anlattığı satırlarda Beyoğlu'nun ön cephelerinin sanat ve kültür içerikli fonksiyonlarını barındıran mekânlara sahip olduğunu belirtmiştir (Tanpınar, 2008, s. 176). Öğrenci de kesit çalışmasında, ön cephedeki üst kültür ortamının yanı sıra tıpkı bugün de olduğu gibi, Beyoğlu'nu Beyoğlu yapan kozmopolit niteliklerin, çok kültürlü karakterin ve canlıığın, o dönemlerde de bir sonraki dizide olduğunu vurgulamak istemiş, bu vurguyu da canlı renk kullanımı ile gerçekleştirmiştir. Metinde sözü edilen kültürel fonksiyon, kesitte tipografik aktarım yöntemi ile soyutlanmıştır (Şekil 6).

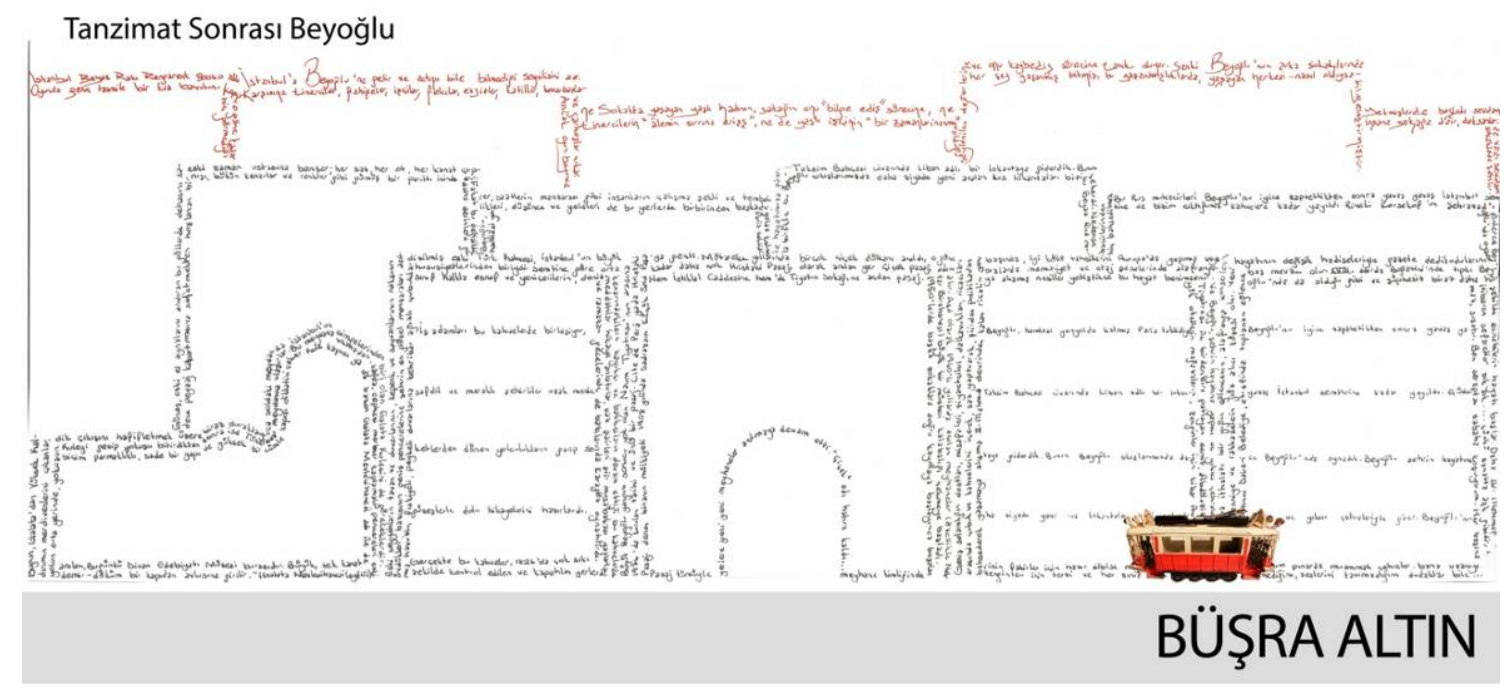

Şekil 6: Edebiyat ortamının kamusal alana yansıması

Tanpınar'ın "Gümrükten geçen her şey müslümanlaşıyordu" sözü, metinde, kültürel değişimin resmi kontrol noktasında gerçekleştiği şeklinde açıklanmaktadır (Tanpınar, 2008, s. 126). Öğrenci çalışmasında, gümrüğün bir kırılma çizgisi (ve bir tür filtreleme mecrası) olarak kullanıldığını ve sözünü ettiği bu kırılmanın; önceki renkleri, farklı biçimleri ve çeşitliliği tek tipleştirme durağı olarak algıladığını aktarmıştır (Şekil 7). Metnin aynı yerinde bu farklılıkların ve çeşitliliklerin "müslümanlaşarak" geldiği yeni durum bir orkestra metaforu ile aktarılmış, "Büyük orkestranın içinde münferit sazlar kendiliklerinden kaybolurdu" (Tanpınar, 2008, s. 126) şeklinde ifade edilmiştir. Yazarın vurguladığı ve olumladığı "uyum" ve "birliktelik" içerikli alt metni, kesitte eleştirilmiş ve "tek tipleştirme" "türdeşleştirme" eğilimi olarak yorumlanmıştır. 
Büyük orkestranın içinde münferit sazlar kendiliğinden kaybolurdu.Çünkü asıl yayı gösteren şeyler bizimdi.Bunlar şehrin kendisi, bizim olan mimarlık, bizim olan musiki ve hayat, nihayet hepsinin üzerinde dalgalanan hepsinin üzerinde dalgalanan hepsini kendi içine alan, kendimize mahsus duyguları, hüzünleri, adece bizim olan zaman...

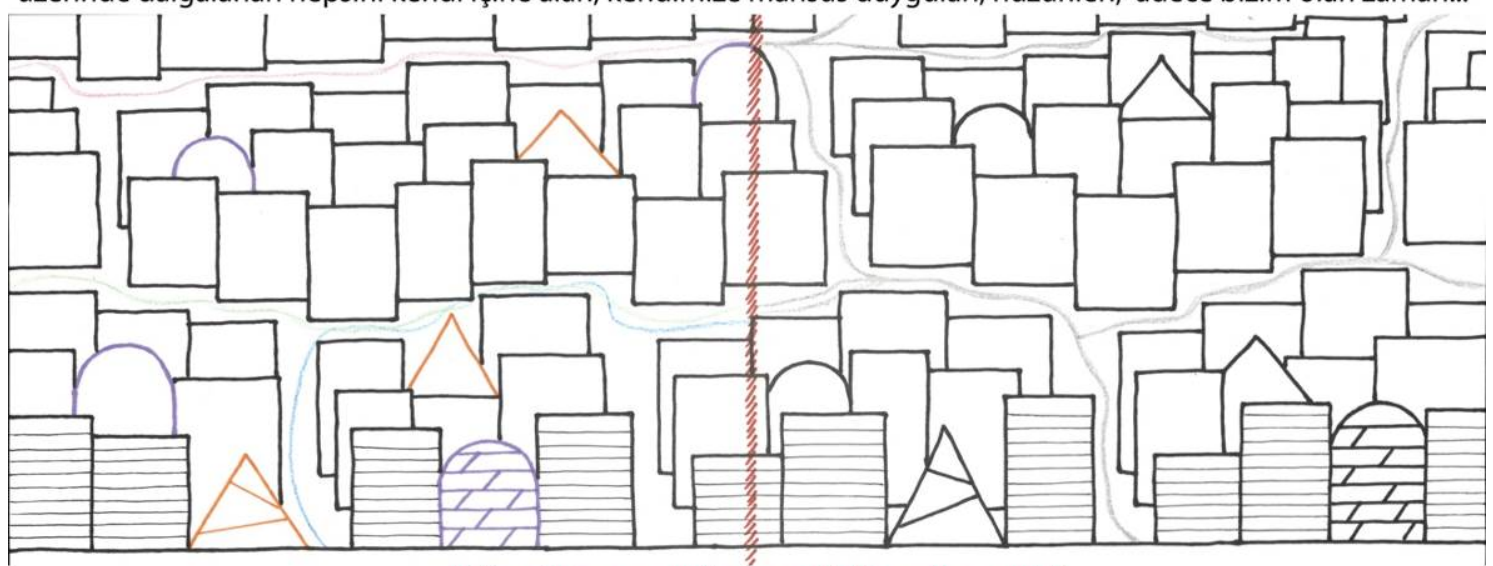

"Gümrükten geçen herşey müslümanlaşıyordu"

BÜŞRA ALTIN

Şekil 7: Kamusal alanda ahenk ve ayrıksılık

Eski mahallelerde, insanların yakın çevresindeki mezarlıklarla ilişkilerinin olduğuna değinen ve bunun artık değiştiğine hayıflanan Tanpınar'ın sözleri (Tanpınar, 2008, s. 105) öğrenci çalışmasında, değişimin şehrin enine büyümesi kadar düşeyde büyümesiyle de ilişkili olduğu ileri sürülmüştür. Çalışmada; yapılar yükseldikçe, temellerin derinleşmesi, toprak altındaki geçmiş kuşaklarla olan bağların yitirilmesine ve temel için aşağılara doğru derinleşildikçe bu yığına yaklaşılmadığı, tam tersine, geçmişe ait bu yığının daha derinlere itildiğine vurgu yapılmıştır (Şekil 8). Kesit çizgisinin geometrik boyutlarının genişletildiği bu çalışma, mekânlarla kurulan metafizik ilişkilerin çalışıldığı, kutsallığın mekân algısına yansımasının işlendiği bir kesit örneğidir.

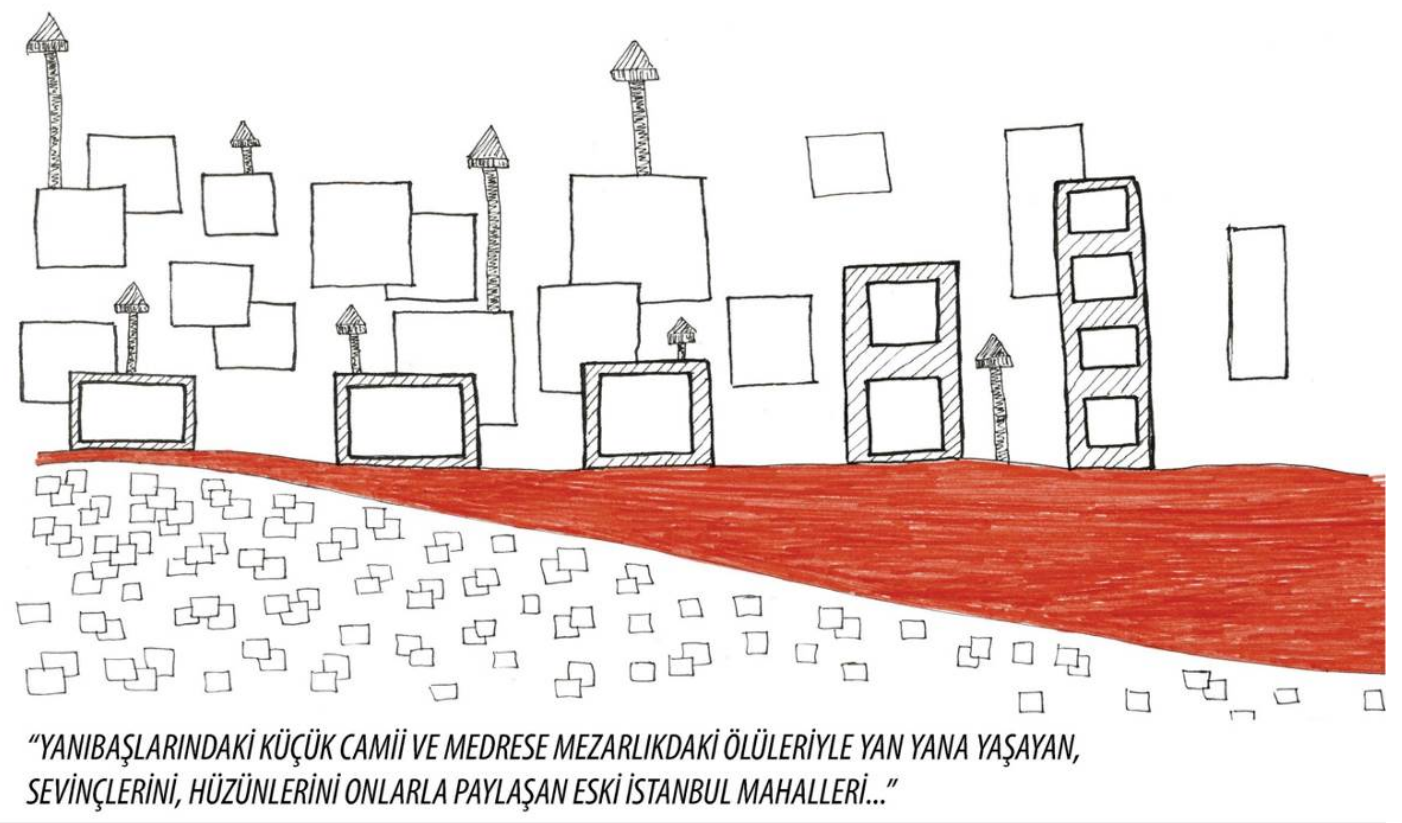

BÜŞRA SARI

Şekil 8: Mezarlıklarından uzaklaşan yeni yapılaşmalar. 
Mahalle yaşamındaki fiziki değişimin bir uzantısı olarak, insani ilişkilerin dönüştüğünü ileri süren bir çalışma, bu dönüşümü formlarla vurgulamayı denemiş, yapı formu olmasa da mahalle içi ilişkilerin daha yumuşak ve esnek biçimlerden, daha keskin sivri ve bir arada bulunmaya elverişli olmayan biçimlere dönüştüğünü vurgulamıştır (Şekil 9). Tanpınar'ın mahallenin yerini, "Alt kat ile üst katın habersizliği, ölümüne dirimine kayıtsızlığı" olarak vurguladığı mahalle kaybı öğrencilerin günümüzde de geçerli olduğunu düşündükleri bir ilişki biçimidir (Tanpınar, 2008, s. 131). Eski evlerdeki ahşap konstrüksiyon ile yeni betonarme binalar arasındaki zıtlıkta üçgen formun, zorlukla dengelenebilen, kesişimlerin en az seviyeye indiği, kırıcı ve sivrilmiş ilişki biçimlerini yansıttığı vurgulanmıştır.

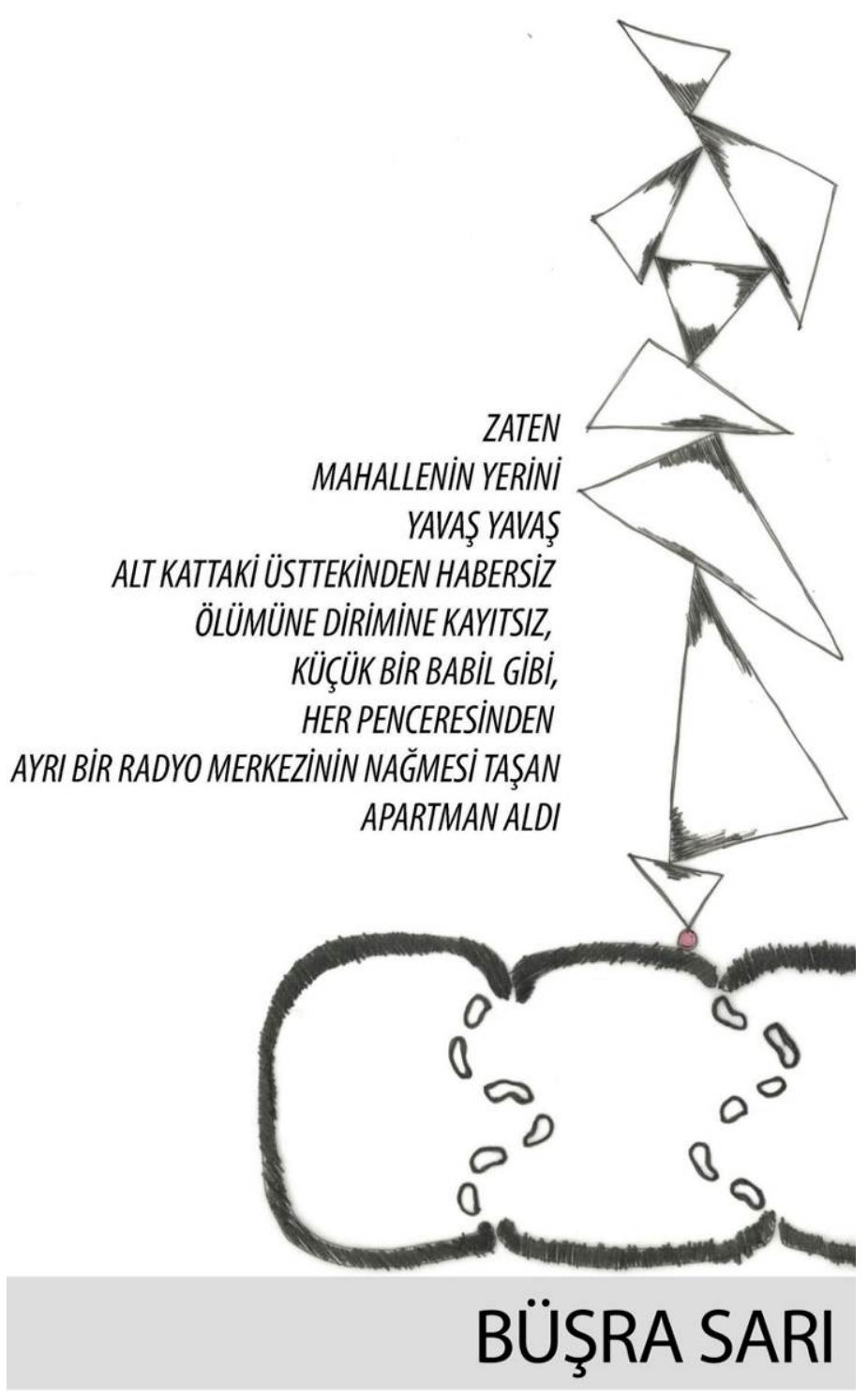

Şekil 9: İnsan ilişkilerindeki değişimin geometrik biçimlerle ilişkilendirilmesi

Mahalle yaşamındaki ses unsurunun yok oluşuna değinen satırlarda Tanpınar, sokak satıcılarının eski dönemlerde evlerin içindeki insanlara etki ettiğini, günün saatlerinin rengini verdiğini belirtmiştir (Tanpınar, 2008, s. 127). Bu temayı çalışan öğrenci, sokak satıcısının sesini grafikleştirdiği kırmızı renkli ses dalgası efektinin geçmişte, binaların içine işler ve kişileri sarıp sarmalarken, zaman içerisinde bu satıcıların mahalle kesitinde toprak altına doğru kaybolduğunu ve binaların içindeki yalnız bireylere ulaşamadan, sesin, bina kesitlerine takılıp kaldığını aktarmaya çalışmıştır. Öğrenci; 
Tanpınar'ın bu duygusunu aktarırken, günümüzdeki durumu da, bu tür sokak satıcılarının varığının sesi ile değil ama edebiyat metinlerindeki varlığı ile izlenebildiği yorumunu yapmıştır. O. Pamuk'un romanlarından "Kafamda Bir Tuhaflı"ta (Pamuk, 2014) ana karakter olarak sokak bozacısını seçmiş olmasını kesitine taşıyan çalışma, satıcıların seslerinin ve varlıklarının kesit altında kalsa da, satıcıya ait bilginin şehrin keşmekeşine ve kalabalıklığına rağmen sürdüğünü ve yok olamayacağını sadece biçimsel bir değişikliğin olduğunu vurgulamıştır (Şekil 10).

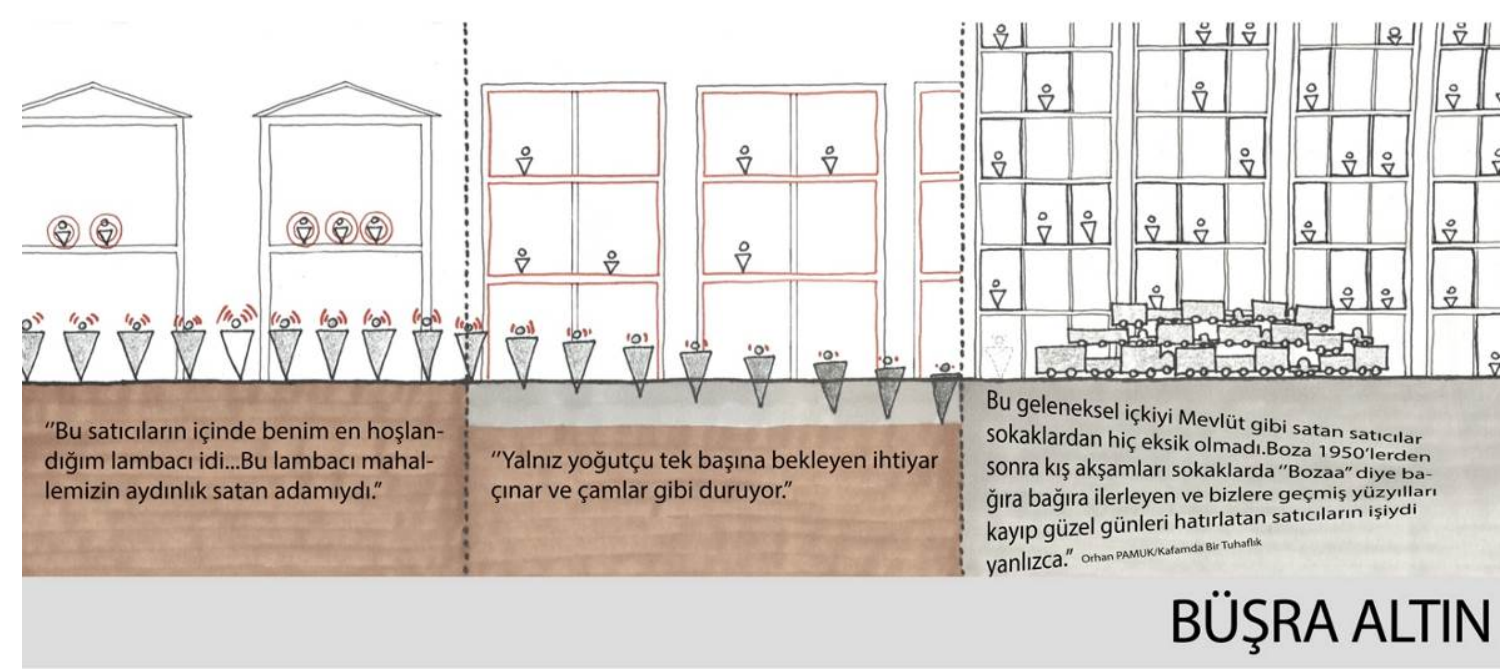

Şekil 10: Kamusal alandaki seslerin edebiyat metinleri içerisindeki serüveni

\section{SONUÇ YERINE: ŞEHIRLERDEKI DEĞişiMiN IZLERi}

Tanpınar'ın şehir metinlerinde yer alan konulardan bu çalışmaya aktarılan farklı ölçeklerdeki unsurlar; kamusal alan, toplu taşıma araçları, mezarlıklar, hapishaneler gibi çeşitlilikler göstermekle birlikte, çalışmaların kritik edildiği jürilerde ve üretim aşamalarında en çok tartışmaya açılan konu spesifik olarak mahalleler olmuştur. Kesit çizgileriyle yorumladıkları tüm metinsel verilerin genel bir değerlendirmesi yapılacak olursa, öğrencilerin, şehir mekânlarına ve bu mekânlardaki değişimleri gözlemleme becerileri, edebiyat metinleri üzerinden yaptıkları mekânsal keşifler ile zenginleşmektedir. Çalışma kapsamında ağırıılı olarak tartışılan ve Tanpınar'ın "fakir mahalleler" olarak andığı mahalle ortamı, günümüz şehirlerinde de kuşkusuz varlıklarını sürdürmektedir. Bu mahalleler, geleneksel mahallenin fiziki unsurlarını sürdürmese de sosyal-toplumsal ilişki ağları bağlamında mahalle karakteristiğinin izlerinin kolaylıkla okunabildiği ortamlardır.

Tanpınar; sesi, ölüleri, binaları gibi; farklı pek çok unsuru ile mahallenin kendisinin kaybolduğunu belirtmiştir. "Bugün artık yalnız şehrin şurasına burasına dağılmış eski, fakir mahalleler var" tespiti (Tanpınar, 2008, s. 130-1) 1950'li yıllara ait. 2000'li yıllarda ise durum oldukça farklı. Tanpınar'ın sözünü ettiği nostaljik mahalle görüntüsü içinde olmamakla birlikte, "fakir mahalle"ler şehrin sadece şurasında burasında değil, her yerinde ve hatta tam da merkezindedir. Geleneksel biçimleri koruyarak değil, kendi mahalle seslerini ve ilişki biçimlerini oluşturarak varlar. Öğrenci çalışmalarının neredeyse tümünün, bu ilişkilerin yitirildiği, artık var olmadıkları yönündeki algıları ve 
işlerini bu doğrultuda işlemeleri, büyük oranda, bu mahallelerde yaşamıyor olmaları, hatta bu mahallelerden haberlerinin dahi olmamasından kaynaklanmaktadır. Oysaki fakir mahalleler, "semt"lerden oldukça başka gündelik yaşamlarıyla "mahalle" olarak varlıklarını sürdürmektedirler. Dolayısıyla değişim olgusu üzerinde durulan öğrenci çalışmalarında şehir mekânlarındaki fiziksel değişimin hızı sadece yıkıcı etkisiyle algılanmaktadır. Fiziki gözlemlerle mahalleler eskiye -geleneksele- dair bir iz barındırmıyor izlenimi vermektedir. Ancak mahallelerdeki gündelik yaşam, mekân kullanım alışkanlıkları geniş sürelerde gözlendiği takdirde, fiziki mekânda görülemeyen izlerin, alışkanlıklarda ve gündelik pratiklerde varlığını sürdürdüğü keşfedilebilir. Mahalleler değişmiştir ama dönüşmemiştir. Fiziki görüntüsü değil ama mahallelerin simgesel gücünün korunduğu çok sayıda örnek bulunmaktadır. Toplumsal farklılıkların oluşum hızı ile mekânsal değişimin hızının karşılaştırılması, değişim ve dönüşüm olguları arasındaki ayrımı ortaya koyacak çalışmalar olacaktır.

"Eski şeyleri kendileri için sevmiyoruz. Bizi onlara doğru çeken bıraktıkları boşluğun kendisidir. Ortada izi bulunsun veya bulunmasın, içimizdeki didişmeden kayıp olduğunu sandığımız bir tarafımızı onlarda arıyoruz" (Tanpınar, 2008, s. 207). Bu çalışmadaki arayış Tanpınar'ın sözünü ettiği, içimizdeki boşluğu doldurmak için yapılmıştır. Tanpınar; metinlerinde, mekânı geometrisinden sıyırıp, yaşanmış bir alana, ruh gücünü verdiği bir yere dönüştüren bir yazardır (Ağbaba, 2016, s. 42). İstediğinde eski şeylere erişemeyip; şiire ve yazıya döndüğünü söyleyen Tanpınar gibi öğrenciler de yazarın metinlerine ve kişisel kesitlerine dönmek üzere isteklendirilmişlerdir. Tanpınar; "Aramak ve bütün kapıları çalmak kâfidir" (Tanpınar, 2008, s. 208) demekte. Bu çalışma kapsamında gerçekleştirilen arayışın sonunda değerli birşey bulundu mu sorusu, Tanpınar'ın tespitiyle yanıtlanabilir: Aramak kâfidir...

\section{KAYNAKLAR}

Ağbaba, Serdar, "Ahmet Hamdi Tanpınar'ın Eserlerinde Mekân-Birey Algısı", Karahindiba Edebiyat Dergisi, İstanbul 2016, Yıl 1, Sayı 5, s. 38-42.

Bafna, Sonit, "How architectural drawings work and what that implies for the role of representation in architecture", Journal of Architectural Education, 2008, Cilt 13, Sayı 5, s.535-564.

Calvino, Italo, Görünmez Kentler, Yapı Kredi Yayınları, İstanbul 2002.

Çağlar, Nur ve Ultav, Zeynep Tuna, "Emile Zola Yazınından Mimari/Kentsel Mekâna Dair Okumalar ve Düşünceler", Hacettepe Üniversitesi Edebiyat Fakültesi Dergisi, Cilt 21, Sayı 2, Ankara 2004, s. 43-60.

Dellaloğlu, Besim, Bir Tanpınar Fetişizmi, Ufuk Yayınları, İstanbul 2013.

Engigün, İnci, Günlüklerin Işığında Tanpınar’la Başbaşa, Dergah Yayınları, İstanbul 2008.

Gariper, Cafer, "Yalnızız Romanında Mekânın Poetikasızlaşması ve Ütopik Dünya Olarak Simeranya", Erdem Dergisi, Sayı 62, İstanbul 2012, s. 41-58.

Gürer, Tan Kamil ve Yücel, Atilla, "Bir Paradigma Olarak Mimari Temsilin İncelenmesi", itüdergisi/a, Cilt 4, Sayı 1, İstanbul 2005, s. 84-96.

Hewitt, Mark, "Representational Forms and Modes of Conception; an Approach to the History of Architectural Drawing", Journal of Architectural Education, Cilt 39, Sayı 2, 1985, s.2-9. 
Korkmaz, Ramazan "Romanda Mekânın Poetiği", Ed.: A. Kulhanlıoğlu ve S. Eker, Edebiyat ve Dil Yazıları Mustafa İsen'e Armağan, Grafiker Yayıncılık, Ankara 2007, s. 399-415.

Pallasma, Juhani, Tenin Gözleri, Yapı Endüstri Merkezi Yayınları, İstanbul 2011.

Pamuk, Orhan, Kafamda Bir Tuhaflık, Yapı Kredi Yayınları, İstanbul 2014.

Şahin, İbrahim, Haz ve Günah, Kapı Yayınları, İstanbul 2012.

Şahin, Veysel, "Kimliksel Değerlerin Çatıştığı Mekân: "Sinekli Bakkal" Romanında Yapı ve İzlek”, Turkish Studies, Cilt 6, Sayı 3, İstanbul 2011, s. 1549-1580.

Şenel, Ayşe Nur, "A reading of the late 19th-century Istanbul public life and space through the tanzimat novels", Basılmamış Yüksek Lisans Tezi, İzmir Yüksek Teknoloji Enstitüsü, Mimarlık Fakültesi, İzmir 2010.

Şengül, Mehmet Bakır, "Romanda Mekân Kavramı", Uluslararası Sosyal Araştırmalar Dergisi, Cilt 3, Sayı 11, İstanbul 2010, s. 528-538.

Tan, Funda, "Çizim Mimarlığı: Mimari bir Motivasyon Olarak Çizim", Basılmamış Yüksek Lisans Tezi, İstanbul Teknik Üniversitesi Fen Bilimleri Enstitüsü, İstanbul 2013.

Tanju, Bülent, Tereddüd ve Tekerrür, Akın Nalça Yayınları, İstanbul 2007.

Tanpınar, Ahmet Hamdi, Beş Şehir, Dergah Yayınları, İstanbul 2008.

Turan, Bülent Onur, "21. Yüzyıl Tasarım Ortamında Süreç, Biçim ve Temsil İlişkisi”, Megaron, Cilt 6, Sayı 3, İstanbul 2011, s. 162-170.

Whorf, Benjamin Lee, Language, Thought and Reality, Cambridge, Technology Press of Massachusetts Institute of Technology, Cambridge 1956.

Zariç, Mahfuz, "Yeni Eleştiri Kuramından Akademik Eleştiri Yöntemine", International Journal of Languages Educating and Teaching, Cilt 3, İstanbul 2014, s. 99-121. 